DOI 10.14746/ppuam.2019.9.02

\author{
Tomasz SójKa
}

\title{
The Civil Liability of Asset Managers - a Polish Perspective ${ }^{1}$
}

\section{Introduction}

This paper focuses on the civil liability of asset managers in Polish law. Following the transformation of the economic system and the development of the capital market in Poland, the importance of asset management has been gradually increasing, though it remains disproportionally lower when compared to the role of collective asset management in the form of investment funds. ${ }^{2}$ In practice, individual asset management services are available to wealthy clients only. ${ }^{3}$ Even though the practical importance of this institution has been growing, it has not yet been thoroughly discussed in legal literature or case law. ${ }^{4}$

A client who wishes to contract the management of their asset portfolio needs to accept the risk of agency costs, arising from the large scope of discretion awarded to the investment firm for making and executing investment decisions on the client's account. A contract - the typical agency cost-restricting tool - is not sufficient to protect the client, since potentially improper contract performance can be difficult to identify. ${ }^{5} \mathrm{EU}$ law, which has co-shaped the Polish legal system in this respect, regulates the provision of brokerage services on a number of levels. ${ }^{6}$ Consequently, the provision of asset management services is subject to a specific normative dualism. Firstly, these services are provided on the basis of contracts made with investors. Secondly, the provision of brokerage

1 This publication is a result of a project financed by National Centre of Science (Narodowe Centrum Nauki) according to the decision no DEC-2013/09/B/HS5/00289.

2 Cf. S. Buczek ed., Asset Management - zarzadzanie aktywami w Polsce, Warszawa, 2006, p. 9; A. W. Kawecki, Civil Law Legal Systems: Poland, in: Liability of Asset Managers, D. Busch, D. A. DeMott, Oxford 2012, p. 251 et seq., p. 262.

3 Cf. S. Buczek, op.cit., note 1, 9 et seq.

4 However, this is not typical of Poland only: D. A. DeMott, Regulatory techniques and liability regimes for asset managers, "Capital Markets Law Journal” 2012, no. 7/4, pp. 423-431.

5 Ibidem, p. 424.

6 Ibidem. 
services is regulated in an extensive manner in public law based on the MiFID I directive $^{7}$, designed to ensure investor protection. The mutual relationship between these two normative levels is one of the core issues discussed in this paper.

In this context, one important aspect is the private law enforcement of the investment firm's obligations toward its clients - both when it comes to obligations under contract and public law. Importantly, civil law protection awarded to an investment firm's clients is characterized by flexibility ${ }^{8}$, which ensures its effectiveness even in the most untypical circumstances. This flexibility can provide necessary supplementation to the administrative supervision of the compliance of investment firms with their obligations toward their clients.

The chief purpose of both MiFID directives is to harmonize the rules applicable to investment firms providing brokerage services in Europe, and to protect the interests investors using brokerage services. ${ }^{9}$ Although the civil liability of investment firms offering brokerage services is part of what is broadly construed as investor protection, the regulations on this matter have been left to the member states' discretion. There is no doubt that discrepancies between member states in this respect diminish the harmonizing effect of both directives. ${ }^{10}$ This paper sets out to determine the basic rules of civil liability of asset management firms in Polish law, and present suggestions for the most common problems in this field.

\section{The Legal Nature of an Asset Management Contract}

An investment firm undertakes to manage a client's financial instruments and cash in such a way as to ensure attainment of a goal specified in the contract, that is, practically speaking, to generate profit. An investment firm manages its client's asset portfolio on the basis of a relatively broad power of attorney, which authorizes it to acquire and sell financial instruments in the client's name and on their account, though transactions executed by an investment firm in its own name but on the client's account are

7 The directive 2004/39/EC of the European Parliament and the Council of 21 April 2004 on markets in financial instruments amending Council Directives 85/611/EEC and 93/6/EEC and Directive 2000/12/EC of the European Parliament and of the Council and repealing Council Directive 93/22/EEC (EU OJ L 145 of 30.04.2004, p.1. Since 3 January 2018 they should be replaced by the regulations included in its recast version - the directive of the European Parliament and the Council 2014/65/EU of 15 May 2014 on markets in financial instruments and amending Directive 2002/92/EC and Directive 2011/61/EU (EU OJ L 173 of 12.06.2014, p. 349); hereinafter: MiFID II.

8 Ibidem.

9 V. N. Moloney, EU Securities and Financial Markets, Oxford 2014, p. 340.

10 D. Busch, Why MiFID matters to private law- the example of MiFID's impact on an asset manager's civil liability, "Capital Markets Law Journal" 2012, no.7/4, pp. 386-413, p. 388 et seq. 
sometimes encountered as well. ${ }^{11}$ As a result, the obligation to manage the client's assets involves the obligation to make and follow through on investment decisions concerning a portfolio of financial assets belonging to a specific client, in order to generate profit. ${ }^{12}$

When performing its management-related obligations, an investment firm substantially makes investment decisions about the client's account on its own, relying on its own expertise and experience, and enjoys a significant degree of discretion in this respect. The discretion of the investment firm is typically restricted by the client's portfolio management policy, agreed between the parties. ${ }^{13}$ The purpose of this policy is to specify the level of risk applicable to investments made on the client's account to ensure that it matches the client's preferences. The discretional competence of the investment firm to determine the client's financial situation is subject to additional restrictions stemming from the duty of loyalty to the client, which means that this competence may be exercised only in the client's best interests. ${ }^{14}$

In Polish law, basic regulations on asset management contracts are laid out in Article 75 of the Act on Trade in Financial Instruments and the executive deed to this act, namely the Regulation of the Council of Ministers on the procedure and conditions of conduct applicable to investment firms and banks referred to in Article 70(2) of the Act on Trade in Financial Instruments, and to custodian banks (hereinafter: RPCC), which transposed the MiFID I directive to the Polish legal system. ${ }^{15}$

As a rule, investment firms are obliged to act diligently - they must act to maximize the portfolio return (profitability) rate. Such a classification is supported by the fact that asset management outcomes typically do not depend on the efforts of the investment firm alone, but are affected by external factors such as the macroeconomic environment, or market trends, which may result in the loss of value of a specific class of financial instruments. ${ }^{16}$

Given Article 75(1) ATFI, and the general nature of the expression "within the cash and financial instruments entrusted by the client at the asset management entity's disposal", one must assume that the investment firm can also execute transactions involving the acquisition and sales of financial instruments on the client's account, but in its own name. In other words, under Article 75(1) ATFI the term 'asset management' is inclusive

\section{Ibidem.}

12 Ibidem.

13 Ibidem.

14 On the legal nature of the portfolio management contract in Polish law see: A. Chłopecki in:, System Prawa Prywatnego vol. 19, ed. A. Szumański, Warszawa 2006, p. 972 et seq. Likewise, P. Zapadka, in: M. Wierzbowski, L. Sobolewski, P. Wajda, Prawo rynku kapitatowego. Komentarz, Warszawa 2014, p. 905.

15 Regulation of the Council of Ministers on the procedure and conditions of conduct applicable to investment firms and banks referred to in Article 70(2) of the Act on Trade in Financial Instruments, and to trust banks (consolidated text: Journal of Laws 2015.878 as amended).

16 Cf. A. Chłopecki, op.cit., note 13, 972 et seq. Likewise P. Zapadka, op.cit., note 13, pp. 905-906. 
of situations where the investment firm, as a type of trust, manages financial instruments which formally belong to it, in its client's own interests.

\section{Public Law Regulations Applicable to Asset Management}

\section{Introduction}

The MiFID I and MiFID II directives subject asset management to general rules applicable to brokerage activity. Polish RPCC rules, implementing MiFID provisions, set forth a number of requirements for investment firms offering asset portfolio management services. These rules include the requirement to obtain a license from a supervisory body to conduct such activity. The management itself is subjected to general provisions on the conduct of business rules, which include the investment firm's duty of loyalty to the client, their pre- and post-contract information and disclosure obligations, and the pre-contract 'Know Your Client' procedure, for establishing whether a specific service is appropriate for the client (see Article 19 MiFID I and Articles 24-25 MiFID II). When it comes to the last of the obligations mentioned above, investment firms have more explorative obligations in this respect, all of which are intended to help ascertain the client's investment goals, financial situation, risk appetite and investment experience (Section 16(1) and 16(5) RPCC).

\section{The Public Law Nature of the MiFID Rules}

Pursuant to the prevailing opinion in the legal literature of most European countries, rules set forth in the MiFID directive are, as such, public law rules. They impose certain obligations on investment firms, and their enforcement has been generally entrusted to supervisory authorities (cf. Article 167 ATFI). ${ }^{17}$ However, it is important to note that Italian law assumes the dual - public and private law - nature of at least some of these rules. ${ }^{18}$ Additionally, certain representatives of the German legal sciences support this view. ${ }^{19}$

17 V. I. Koller in: Wertpapierhandelsgesetz, H. D. Assmann, U. H. Schneider, Köln, 2012, p. 1361 et seq.; Moloney, op.cit., note 8, 601. Paradoxically, public law rules laid down in the MiFID directive on the provision of investment services are derived from private law of certain member states (mainly Germany and the Netherlands), and, to be more specific, from the case law on contractual obligations of investment firms toward their clients - see O. O. Cherednychenko, Full harmonization of Retail Financial Services Contract Law in Europe in: Financial Services, Financial Crisis and General European Contract Law, ed. S. Grundmann, Y. M. Atamer Alphen aan den Rijn 2011, 249, footnote 142.

18 D. Busch, A. DeMott, op.cit., note 1, 538.

19 T. M. J. Möllers in: Kölner Kommentar zum WpHG, ed. H. Hirte, T. M. J. Möllers, Köln-Berlin-München 2007, p. 1276. V. M. Casper, C. Altgen, Civil Law Legal Systems: Germany, in: op.cit., D. Busch, A. DeMott, note 1,101 and literature referenced therein. 
The key argument in favour of the view that most of the norms arising from the MiFID directive and implemented in Polish law are of a public law nature, is that they are applicable regardless of the contract between the client and the investment firm. What's more, their aim is typically not to protect the interests of a specific client only, but also to protect the more broadly construed public interest, such as building social trust in capital market institutions and equity market efficiency. Nonetheless, it seems that the dual - public/private law - nature of any specified rule implementing the MiFID directive should not be excluded in advance. This issue should instead be settled on a case-bycase basis, through interpretation of relevant provisions of national law shaping a specific institution.

However, the public law nature of the MiFID directive's rules does not change the fact that some of them directly reference the rules on providing brokerage (investment) services by investment firms (conduct of business rules), and thereby to the relationship between service provider and client, which is also a subject of contractual civil law relationships. This in turn generates a number of detailed legal issues related to the mutual relationships between these two legal normative layers.

There are no major doubts in legal literature that public law rules applicable to the provision of brokerage services affect, to a certain degree, the interpretation of private law and the content of the contractual duties of institutions providing brokerage services. In German doctrine it has been assumed that public law rules have a kind of 'radiating' effect (Austrablungseffekt) on civil law relationships. ${ }^{20}$ Some scholars even argue that the national legislator cannot completely exempt civil law relationships from the influence of the MiFID directive, since this would undermine the possibility of achieving certain objectives of this directive, including investor protection. ${ }^{21}$

When it comes to Polish law, it is important to note that the rules laid down in the MiFID directive and provisions implementing this law may affect the interpretation of contracts on brokerage services (Article 65 of the Polish Civil Code), as well as relevant provisions of the Civil Code on the manner of performance of obligations under these contracts (Articles 354 and 355 of the Civil Code). In the latter case, public law provisions can provide guidance when interpreting the "social-economic purpose of an obligation' of an investment firm in a brokerage contract, as well as the relevant rules of conduct and customs (Article 354 of the Civil Code) ${ }^{22}$. This is a consequence of the fact that Article $354 \mathrm{CC}$, in conjunction with Article 83a ATFI, serves as a normative basis

20 See e.f. I. Koller, op.cit. note 16, 1361; M. Casper, C. Altgen, op.cit. note 18, 105 and literature listed therein. See also: M. Tison, The civil law effects of MiFID in a comparative law perspective, in: Festschrift für Klaus J. Hopt. Unternebmen, Markt und Verantwortung, Berlin-New York 2010, p. 2621 et seq.

21 M. Tison, op.cit., note 19, 2622 et seq.

22 Likewise: A. Kawecki, op.cit. note 1, 262. 
for an investment firm's obligation to act in its client's interest and observe the duty of loyalty. Pursuant to Article 83a(3) ATFI, an investment firm providing brokerage services must take account of the client's best interests.

As a result, we must assume that courts settling cases of improper performance of contractual obligations by brokerage firms should take special account of the content of obligations imposed on such firms by public law. This pertains to the obligation to exercise orders on the most favourable terms to the client (see section 47 et seq. RPCC), as well as other factors an investment company must consider when deciding where to execute an order (section 48(1)-(4) RPCC). However, civil courts are not bound by the verbatim wording of the provisions of administrative law included in the regulation, but rather must interpret the contract binding the parties ${ }^{23}$ under Article $65 \mathrm{CC}$ on a caseby-case basis.

There is much more controversy when it comes to the question of whether civil courts can interpret the investment firm's contractual obligation to act in their client's interests in a more restrictive manner than prescribed in the MiFID directive. It is also disputable whether MiFID directives restrict the Polish legislator's or Polish courts' freedom to shape public law rules determining relationships that create obligations between brokerage service providers and their clients.

Comparative studies point to two diverse views. The first assumes that since the $\mathrm{Mi}$ FID directive does not interfere with the content of contracts made in member states, but only sets public law rules, national legislators and judicial authorities enjoy full discretion in terms of determination and interpretation of private law rules. ${ }^{24}$ Following this reasoning, the investment's firm duty of care and loyalty stemming from public law is a specific interpretative guideline for civil courts settling issue around the specific content of the civil law duty of care and loyalty, without imposing restrictions on civil courts in this respect. ${ }^{25}$

The second view is that the freedom of member states to determine and interpret private law rules applicable to brokerage (investment) services is hardly compatible with the maximum standard of harmonization introduced by the MiFID directive and its objectives. Pursuant to the prevailing view in the literature, MiFID directive rules should be viewed as maximum regulation, which is supported by the detailed nature of these provisions and their objective - the integration of the European capital market and

23 M. Casper, C. Altgen, op.cit. note 18, 105.

24 M. Tison, op.cit. note 19, 2632; O. O. Cherednychenko, op.cit., note 16, 254.

25 See the British Appellate Court's judgement: Gorbam \& others v. British Telecommunications plc, Trustees of the BT Pension Scheme \& Standard Life Assurance Company, 20001 WLR 2129 and the Dutch Supreme Court's judgement: De Tv. Dexia Bank Nederland NV, HR 5 Jun. 2009, RvdW 2009, 683; Levob Bank NV v. B and GBD, HR 5 June 2009, RvdW 2009, p. 684; Stichting Gedupeerden Spaarconstructie v. Aegon Bank NV, HR 5 June 2009, RvdW 2009, p. 685 - quoted in: O.O. Cherednychenko, op.cit., note 16,254 et seq. 
facilitation of the cross-border operations of investment firms. ${ }^{26}$ This would mean that member states cannot introduce regulations governing brokerage services offered by investment firms that would be stricter than EU law, as this would hinder cross-border provision of such services on the EU common market. ${ }^{27}$ The introduction of different civil law regulations as applicable to contracts would form an obstacle to the provision of cross-border brokerage services, as the investment firm would have to adjust its operations to mandatory private law rules which determine the content of their contractual relationships. ${ }^{28}$

In this matter, I support the relative autonomy of member states' private law. It seems that the national legislator can shape the private law rules which impose additional or more stringent obligations on brokerage firms than the duties laid down in the MiFID directive. Likewise, civil courts in member states can also independently interpret contracts for investment services between investment firms and their clients, which includes the right to infer more extensive obligations of the service provider than set forth in the MiFID directive ${ }^{29}$. Contracts for investment services can broaden the scope of duties of investment firms towards their clients. ${ }^{30}$

Investor protection, guaranteed by the MiFID directive, is based on the assumption that the institutions operating under this directive will do so in the same manner in every single member state. However, it is obvious that this assumption is not in line with the facts - terms and conditions governing the provision of brokerage (investment) services differ from state to state, and from multiple perspectives: the legal systems, institutional environments, level of individual investors' education, etc. The MiFID directive ensures the appropriate level of security in countries whose capital market is well developed. Meanwhile, in countries such as Poland, where the level of investor education is low, the protection that the MiFID directive ensures may turn out to be insufficient. ${ }^{31}$ In this context 'local' private law can serve as an effective, case-tailored supplementation, remedying the potential gaps in investor protection. ${ }^{32}$

However, there are some limits to the autonomy of private law in this field. It seems that the extension of a brokerage firm's duties based on contractual provisions cannot

26 P. O. Mülbert, The Eclipse of Contract Law in the Investment Firm-Client Relationship: The Impact of the MiFID on the Law of Contract from a German Perspective in: Investor Protection in Europe. Corporate Law Making, The MiFID and Beyond, ed. G. Ferrrarini, E. Wymeersch, Oxford 2007, 300 et seq.

27 M. Tison, op.cit., note 19, 2632; O. O. Cherednychenko, op.cit., note 16, 254.

28 P. O. Mülbert, op.cit. note 25, 300 et seq.

29 Likewise: A. Kawecki, op.cit. note 1, 263.

30 More on the subject see below.

31 L. Enriques, Conflict of interest in Investment Services: The Price and Uncertain Impact of MiFID's Regulatory Framework in: G. Ferrrarini, E. Wymeersch, op.cit., note 25334 et seq.

32 Ibidem. 
completely prevent the attainment of the MiFID directive's objectives, and the freedom of services on the common market. The obligatory content - that prescribed by imperative legal rules - of contractual legal relationships in the scope under discussion cannot create a situation where investment firms in the EU have to deal with radically diverse systems of service provisions depending on the member state.

\section{Validity of a Contractual Exemption from Duties Laid Down in the MiFID Directive}

We must assume that a contract or its specific provisions, which are less favourable to the investor than public law rules on investment services, are invalid (article 58(1)-(3) CC) 33 . Furthermore, it is also disputable whether an investment firm or a bank's liability for damage arising out of failure to comply with the MiFID directive can be waived. However, it would be admissible to impose additional duties on an investment firm or a bank which go beyond the standard laid down in the MiFID directive. ${ }^{34}$

\section{The Impact of the Infringement of Duties Laid Down in the MiFID Directive on the Validity of Contracts for Investment Services}

It has been assumed in Polish legal sciences that a contract for brokerage services made by an entity running brokerage services without a required license is invalid ${ }^{35}$. This view is consistent with established case law of the Supreme Court on an analogous question of law concerning other regulated types of business activity and with legal literature which supports this reasoning ${ }^{36}$. Also Italy, Ireland and, as it seems, France have adopted a similar view both in legal literature and case law (though in France this issue is still hotly debated in literature and judicial practice is inconsistent). ${ }^{37}$ Nonetheless, it is worth noting that many other EU states represent a different viewpoint, which means that this matter is highly debatable ${ }^{38}$. First of all, it is argued that the system of granting licenses for operations on the financial market is to protect the public interest. Meanwhile, the sanction of invalidity of a legal transaction executed by an unauthorized person is not always in the best interest of the client with whom the contract has been made. ${ }^{39}$

33 A. Kawecki, op.cit., note 1, 263.

34 Ibid.

35 Ibid.

36 Supreme Court judgement of 19 January 2011 V CSK 173/10 on invalidity of a contract for real estate agency conclude by a person without a realtor's license. See also the Supreme Court resolution of 17 July 2007 III CZP 69/07 on invalidity of a contract for real estate management. See also M. Gutowski, Ważność umowy zawartej w zakresie dziatalności licencjonowanej przez osobę nieposiadająca wymaganej licencji, „Monitor Prawniczy” 2009, no. 3, p. 168 et seq.

37 D. Busch, D. A. DeMott, Liability..., p. 542.

38 M. Tison, op.cit., note 19, D. Busch, D. A. DeMott, op.cit., note 1, 542. In German law, see: M. Casper, C. Altgen, op.cit., note 18, 131 et seq.

39 M. Tison, op.cit., note 19. 
I believe that the sanction of invalidity of a legal transaction in the case of an investment firm's infringement of relevant public law rules should be applied cautiously, taking account of the circumstances of a specific case. Contrary to the prevailing view, I believe that a contract for brokerage services concluded by an entity running brokerage services without a required license is valid. I am not persuaded by the opinion, widespread in Polish legal literature and case law, that "since the legislator rations a specific activity and imposes an obligation of a license to run it, it should not accept the existence of valid contracts made by unauthorized entities or extend protection to claims arising out of such contracts". ${ }^{40}$ This would mean that the same axiological arguments which support licensing of a specific activity underpin the view that contracts made by entities without the required license should be eliminated, making a relevant legal transaction invalid $^{41}$. Meanwhile, we are dealing with two separate issues. It is a separate matter to punish an entity running its business without a license with administrative law or even criminal law penalties, as such penalties 'hurt' primarily the 'perpetrator' who has infringed public interest protected by these rules. Meanwhile, the sanction of invalidity of a legal transaction interferes with the interest of a client who has made a contract with an investment firm operating without a license and is, in a way, a victim of this conduct. From the perspective of the client's interest, the sanction of invalidity of a legal transaction will not always bring about positive effects, as the client will often become aware of the shortcomings of the counterparty after the fact, that is after they have transferred their funds or financial instruments for management, or have used investment consulting services. It may turn out that claims under contract offer a much better protection of the client's interests than claims under unjustified enrichment or potential claims under culpa in contrahendo. ${ }^{42}$

\section{Rules Applicable to “Inducements” Received by Asset Managing Entities}

The European legislator, followed by the Polish one, has introduced public law regulations intended specifically to address the issue of fees received or given by the investment firm in connection with the portfolio management service. This pertains, for instance, to benefits obtained from other investment firms by the agency of which the managing firm executes orders to acquire or sell financial instruments within the managed portfolio in exchange for directing a "stream of orders" to them. One important feature of such inducement is that they may encourage investment firms to infringe their duty of loyalty by using services of investment firms whose terms are not the most favourable (e.g. the cheapest) to the clients. These regulations apply to all benefits related to the provision of

40 M. Gutowski, op.cit., note 35, 173.

41 Ibidem.

42 V. P. Machnikowski, in: System Prawa Prywatnego. Prawo zobowiqzań - część ogólna, vol. 5, ed. E. Łętowska Warszawa 2013, p. 476 et seq. 
brokerage services, without limitation to performances that would typically be classified as 'inducements'. ${ }^{43}$

Section 8 RPCC in conjunction with Article 26 of the directive 2006/73/EC (Article 24(9) MiFID II) introduces a general assumption that an investment firm that gives or is given a benefit in connection with the provision of an investment (brokerage) service infringes the duty of loyalty toward its client. Therefore, the regulations being analysed do not apply to such benefits received or given by the investment firm which are not related in any way to the brokerage service provided to clients. ${ }^{44}$ Furthermore, this assumption does not apply if the investment firm operates on the basis of one of the three exceptions stipulated by these regulations: the first one is rather obvious and pertains to situations where the benefit to the investment firm is paid by the client (section 8(2) RPCC); the second one (section 2(2) RPCC) concerns equally typical benefits such as fees and commissions necessary for the provision of a specific brokerage service (e.g. fees for deposit services, fees for transaction settlement or clearing of the transaction - see Article 24(9) in fine MiFID II) ${ }^{45}$ the third exception applies to all other benefits which were classified as admissible by the legislator. Such benefits must meet two criteria: first, the client has received information on such benefits, their nature, amount or manner of calculation before entering into the brokerage contract; ${ }^{46}$ second, they are received or given to improve the quality of the brokerage service provided by the investment firm to the client (Section 8(2)(3) RPCC). ${ }^{47}$

In the context of the MiFID II directive, the European legislator has decided to go even further when it comes to the restrictions aimed at the protection of investors' interests (see recital $74 \mathrm{MiFID}$ II). An investment firm, as a rule, cannot give or be given any benefits from third parties, from issuers of any financial instruments or providers of financial products. The only exception from this rule are small financial benefits which may improve the quality of service provided to the client and have no negative impact on the investment firm's compliance with its duty to act in the client's best interest and on condition that they have been explicitly disclosed (Article 24(7)(b) and Article $28 \mathrm{MiFID}$ II).

What is more, the European legislator has assumed that benefits received by an investment firm offering portfolio management services in breach of the regulations that restrict the admissibility of accepting such benefits must be transferred to clients (see recital 74 MiFID II). Pursuant to Article 24(9) MiFID II, in relevant cases the investment

43 CESR Level 3 Recommendations on Inducements, Cesr/07-316, 2017.

44 Ibidem, 5.

45 Cf. Maciej Kurzajewski, Ustugi maklerskie, Warszawa 2014, p. 184 et seq.; Cf. CESR Level 3 Recommendations on Inducements. under MiFID, Cesr/07-316, 2017.

46 With respect to the level of detail of the information see also Section 8(3) RPCC.

47 Cf. M. Kurzajewski, op.cit., note 44, 198 et seq. 
firm must also inform the client about mechanisms for transferring the fee, commission, monetary or non-monetary benefit received in relation to the provision of the investment or ancillary service. ${ }^{48}$

The answer to the question whether, in the view of currently binding Polish law, an investment firm providing an investment service to a client has a contractual duty to return the "inducement" to the client may be seen as controversial. It is a consequence of discrepancies concerning the interpretation of the second sentence of Article 740 of the Civil Code introducing the obligation of the service provider to return "everything received from them when performing the order" to the client. Older literature on the topic supported the view that "this kind of benefits should be given to the ordering party", since it "prevents, to a certain extent, improper conduct of the provider" ${ }^{49}$ "The provider accepting the order cannot act in a third party's interest. They cannot accept any gifts, performances or similar benefits from others" ${ }^{50}$

This view does not distinguish sufficiently between the two layers of the issue under discussion, namely: a potential breach of the duty of loyalty to the ordering party which stems from the acceptance of an 'inducement' from a third party, and the obligation to return the benefit under the second sentence of Article 740 of the Civil Code. In consequence, one should agree with the view presented in more recent literature that the provider is not obliged to transfer to the client any benefits obtained in connection with the performance of the order, but for itself, and not for the client. ${ }^{51}$ It is a completely separate matter that the acceptance of a benefit from a third party typically puts the provider in a situation of conflict of interest, which in turn may lead to the breach of the duty of loyalty to the client if the service is not performed in the exclusive interest of the client. ${ }^{52}$ It seems, however, that the task of transposing the MiFID II provisions on inducements to the Polish system will involve legislative changes in this respect, including the introduction of an explicit obligation to return the benefits related to the provision of a brokerage service illegally received by the investment firm.

48 In German law $c f$. M. Casper, C. Altgen, op.cit., note 18,110; P. O. Mülbert, Auswirkungen der art. 19 ff MiFID auf das Zivilrecht am Beispiel von Vertriebsvergütungen im Effektengeschäft der Kreditinstitute, „Zeitschrift für das gesamte handelsrecht“ 2008, no. 172, pp. 170-209.

49 A. Szpunar, in: System prawa cywilnego. Prawo zobowiazań, częsé ogólna, vol. 3, part 2, ed. Z. Radwański Wrocław 1981, p. 398 et seq.

50 Ibid., 398.

51 Ibidem Likewise: K. Kopaczyńska-Pieczniakin: Kodeks cywilny. Komentarz, vol. III, ed. A. Kidyba, Warszawa 2014, p. 627.

52 On this duty $c f$. A. Szpunar, op.cit. note 48, 396 et seq. 
34 | Adam Mickiewicz University Law Review

\section{Civil Liability of the Managing Entity}

A service provider who improperly performs its duty to manage an asset portfolio is liable for damage under Article 471 of the Civil Code. However, it is important to add that such a fact can also be classified as a breach of public law governing this service. A breach of public law rules governing the business conduct with respect to asset management can result in liability for damages under Article 145 of the Civil Code..$^{53}$

Nonetheless, a mere decrease in the value of assets entrusted in management is not tantamount to a breach of the obligation by the managing entity. As a rule, the obligation of the investment firm to manage a portfolio involves a duty of diligent conduct, and not an obligation to attain a specific result. The firm does not guarantee any specific financial results of the service it offers. A decrease of the portfolio value cannot automatically be considered a remediable damage suffered by the investor. A decrease in the value of assets may be caused by factors which are beyond the influence of the managing entity ${ }^{4}$, such as the macroeconomic situation.

Typical examples of a breach of duty by the managing entity include ${ }^{55}$ : asset management incompatible with the client's investment goals agreed between the parties or in breach of the portfolio management policy; acquisition of an asset portfolio without the fundamental analysis required in a specific case; improper advisory of the managing entity when deciding on the portfolio management policy with the client; provision of a service unsuitable for a specific client or transaction churning. ${ }^{56}$

When breached by an investment firm, most public law provisions implementing the MiFID directive into Polish law can create liability for damage toward investors under Article 415 et seq. CC..$^{57}$ It is a consequence of the fact that the direct purpose of these provisions is to protect investors' interest. One case of such a breach is the provision of asset management services without performing the Know Your Client procedure confirming that the service is appropriate for a specific person (section 16(5) RPCC), or, potentially, a breach of the firm's disclosure obligations before entering into a contract for the provision of the service (Article 19(3) of MiFID I directive and section 13 RPCC), in particular the failure to inform the client of risks inherent to investments in a specific type of financial instruments.

As a rule, the damage arising from the breach of the firm's duties is calculated as the difference between the actual value of the asset portfolio and its hypothetical value had the breach not occurred. ${ }^{58} \mathrm{~A}$ damage to be remedied may take the form of a loss

53 M. Casper, C. Altgen, op.cit., note 18, 107; A. Kawecki, op.cit., note 1, 266.

54 C. Benicke, Wertpapiervermögensverwaltung, Tübingen 2006, p. 832 et seq.

55 Ibidem, p. 813.

56 Ibidem, p. 812.

57 Likewise: A. Kawecki, op.cit., note 1, 266.

58 V. Z. Radwański, A. Olejniczak, Zoborwiq̨zania-częśco ogólna, Warszawa 2014, p. 93; M. Kaliński, Szkoda na mieniu i jej naprawienie, Warszawa 2014, p. 188 et seq. 
(e.g. a decrease of the value of a purchased instrument) and lost benefits (e.g. the increase of the value of instruments in which the funds would have been invested). ${ }^{59}$

In this context, a fundamental question typically debated in literature is the scope of analysis of the client's financial situation that is required to determine the amount of damage suffered by them. In particular, it is necessary to determine whether - in order to assess the actual value of the victim's assets after the event causing damage has taken place - one should take account of: (i) the total value of the managed portfolio, that is of all its components, both instruments and cash; or (ii) specified financial instruments or a transaction pertaining to such instruments by which the managing entity breached its obligation. ${ }^{60}$ In practice, to answer this question is to determine whether negative consequences of the event causing damage and pertaining to certain financial instruments can be compensated by benefits generated by other instruments in the same portfolio. ${ }^{61}$

When analyzing this issue from the perspective of Polish law, we must conclude that to determine the actual value of victim's assets it is necessary to take account of the entire financial situation of the victim after the event causing damage occurred, instead of limiting ourselves to direct consequences of such an event. ${ }^{62}$ Meanwhile, the core of the analyzed problem is rather the admissibility of accounting benefits obtained by the client towards damage (compensatio lucri cum damno). The answer to this question depends directly on the nature of the event causing damage and on the type of the infringed management duty. If the infringed duty concerned the entire asset portfolio, to calculate the damage suffered by the client one should take account of the actual value of the entire portfolio, inclusive of potential benefits (compensatio lucri cum damno) arising of improper portfolio management. However, if the infringed duty involved an acquisition of a specific type of assets, for instance shares in X, without relevant fundamental analysis, the procedure applied should be different. In this case, when calculating the actual value of a victim's assets, benefits arising from the purchase of shares in $\mathrm{Y}$ and $\mathrm{Z}$ cannot be used to set off the damage arising from the acquisition of shares in X. It is a consequence of the fact that the damage and benefit were not caused by the same event. ${ }^{63}$

The most pronounced difficulty when calculating the damage involves the determination of a hypothetical value of the managed portfolio assuming that the infringement would not have taken place. One specific feature of liability for infringement of a duty by an entity managing a portfolio of quoted assets is that a model (projection) of a hypothetical value of the managed portfolio assuming that the damaging event has not taken

59 M. Casper, C. Altgen, op.cit., note 18,126; cf. K. Zacharzewski, Szkoda gietdowa i jej naprawienie, Torun 2015, p. 408.

60 K. Zacharzewski, op.cit., note 58, 422 et seq. In German literature v. M. Casper, C. Altgen, op.cit., note 18,127; C. Benicke, op.cit., note 53, 837 et seq.

61 C. Benicke, op.cit., note 53, 837 et seq.

62 Z. Radwański, A. Olejniczak, op.cit., note 57, 93.

63 Ibidem, 94. 
place is required not only to calculate the potential lost benefits ${ }^{64}$, but also the loss of an investment firm's client(damnum emergens). ${ }^{65}$

When developing a model of hypothetical behaviour of a correctly managed portfolio, the primary source of data includes the outcomes of the 'healthy' part of the portfolio. ${ }^{66}$ Such an extrapolation of the correctly managed portion to the entire portfolio is obviously possible only when, first of all, at least a part of the portfolio was managed correctly, and, secondly, the correctly managed portfolio structure is in a specified way similar to the incorrect structure of the entire portfolio. ${ }^{67}$

Nonetheless, the foregoing intellectual operation will be inappropriate if the correct portion of the portfolio, in compliance with the contract, does not correspond to the structure of the incorrect portion of the portfolio. In such a case, to calculate the hypothetical value of the incorrect portion of the portfolio which has been improperly managed, one needs a model based on other, objective ratios. First of all, it is necessary to take account of the contract of management, and the agreed portfolio management policy in particular, in the scope applicable to the portion concerned. If the policy lays down the requirements concerning the structure of this portion of the portfolio, they should obviously be considered, as they narrow down the circle of potential factors that influence the portfolio structure. However, it may be possible to use the value of units in most popular investment funds with a similar management policy as a benchmark. ${ }^{68}$ If relevant data is available, it is also admissible to take account of results generated by other entities managing asset portfolios of a similar structure. ${ }^{69}$ In the process of building the model of hypothetical portfolio value, common sense experience suggests that it is reasonable to conclude that the investment firm would not have left client's funds idle for a longer period without an important reason. ${ }^{70}$

The duty to remedy damage arising out of the breach of a contractual obligation laid down in the contract for portfolio management can be proportionally decreased if the victim has contributed to the damage, pursuant to Article $362 \mathrm{CC}$. The most obvious case of such a contribution in the circumstances being discussed is the provision of untrue or incomplete data of a victim's financial standing and personal situation to the investment firm, which may result in issuing incorrect recommendations with respect to the asset portfolio management. ${ }^{71}$ However, as a rule, the lack of a client's response to the fact that the service has not been performed in compliance with the contract (e.g. excessively risky portfolio management policy) and failure to notify the investment firm

64 Ibidem, p. 93.

65 C. Benicke, op.cit., note 53, 865.

66 C. Benicke, op.cit., note 53, 865.

67 Ibidem, v. M. Casper, C. Altgen, op.cit., note 18, 127.

68 C. Benicke, op.cit., note 53, 846; M. Casper, C. Altgen, op.cit., note 18, 126.

69 M. Casper, C. Altgen, op.cit., note 18, 127.

70 Otherwise: Ibidem.

71 C. Benicke, op.cit., note 53,882. 
of one's complaints or comments cannot be classified as the victim's contribution to damage. ${ }^{72}$ A client using the asset management service is not obliged to monitor on an ongoing basis how the service is being performed and file complaints on the breach of the managing entity's duties. ${ }^{73}$

\section{Conclusion}

In view of the current economic situation, and the forecasted persisting low interest rates, we are likely to observe a gradual increase to the practical importance of asset management contracts in Poland and other countries of Central and Eastern Europe. Consequently, the significance of civil law liability of investment firms for improper performance of asset management contract will also become more pronounced, since shortcomings in this respect are difficult to identify by supervisory bodies and are typically of incidental nature.

MiFID I-derived public law regulations on provision of brokerage services are particularly important for the countries of Central and Eastern Europe, given the relatively limited experience of the judiciary and legal scholars in settling disputes and complex legal problems arising in this context. The public law duty of loyalty of an investment firm to its clients introduced by the MiFID directives (Article 19(1) of MiFID I and Article 24(1) of MiFID II) is a new category in the legal system and legal discourse of these states and has not been fully explored yet. It stems from the institution of fiduciary duties developed in the common law system that allows for flexible limitation of the conduct of a fiduciary enjoying discretional competence to affect the financial standing of the person entrusting their assets. ${ }^{74}$

In a way, the investment firm's duty of loyalty to its client introduced by the MiFID directives plays an important educational role transforming the legal culture of these states. Consequently, it can be assumed that unlike certain mature capital markets, such as the German market, where the MiFID I directive was described as potentially relaxing the excessive severity of the private law and conspicuous activity of courts in terms of investor protection, in Poland and probably in other 'new Europe' states alike it will rather motivate supervisory authorities and civil courts to become more active in this area.

72 Ibidem, 882 et seq.

73 For exceptions from this rule v. Benicke, op.cit., note 53, 890 et seq. M. Casper, C. Altgen, op.cit., note 18,128 . et seq.

74 V. K. Pistor, C. Xu, Fiduciary Duty in Transitional Civil Law Jurisdictions Lessons from the Incomplete Law Theory, in: Global Markets, Domestic Institutions: Corporate Law and Governance in a New Era of Cross-Border Deals, ed. C. J. Milhaupt, New York 2003, p. 78 et seq. 
38 | Adam Mickiewicz University Law Review

\section{Literature}

Benicke C., Wertpapiervermögensverwaltung, Tübingen 2006.

Buczek S. ed., Asset Management - zarzqdzanie aktywami w Polsce, Warszawa, 2006.

Busch D., Why MiFID matters to private law-the example of MiFID's impact on an asset manager's civil liability, "Capital Markets Law Journal” 2012, no 7/4.

Casper M., Altgen C., Civil Law Legal Systems: Germany, in: D. Busch, D.A. DeMott, Liability of Asset Managers, Oxford 2012.

Cherednychenko O. O., Full harmonization of Retail Financial Services Contract Law in Europe, in: Financial Services, Financial Crisis and General European Contract Law, ed. S. Grundmann, Y. M. Atamer Alphen aan den Rijn 2011.

DeMott D. A., Regulatory techniques and liability regimes for asset managers, "Capital Markets Law Journal" 2012, no. 7/4.

Enriques L., Conflict of interest in Investment Services: The Price and Uncertain Impact of MiFID's Regulatory Framework, in: Investor Protection in Europe. Corporate Law Making, The MiFID and Beyond, ed. G. Ferrrarini, E. Wymeersch, Oxford 2007.

Gutowski M., Ważność umowy zawartej w zakresie dziatalności licencjonowanej przez osobe nieposiadajacq wymaganej licencji, „Monitor Prawniczy” 2009, no. 3.

Kaliński M., Szkoda na mieniu i jej naprawienie, Warszawa 2014.

Kawecki A. W., Civil Law Legal Systems: Poland, in: Liability of Asset Managers, D. Busch, D. A. DeMott, Oxford 2012.

Koller I., in: Wertpapierbandelsgesetz, ed. H. D. Assmann, U. H. Schneider, Köln, 2012.

Kopaczyńska-Pieczniak K. in: Kodeks cywilny. Komentarz, vol. III, ed. A. Kidyba, Warszawa 2014.

Kurzajewski M., Ustugi maklerskie, Warszawa 2014.

Machnikowski P., in: System Prawa Prywatnego. Prawo zobowiązań - czesśc ogólna, vol. 5, ed. E. Eętowska Warszawa 2013.

Möllers T. M. J., in: Kölner Kommentar zum $W p H G$, ed. H. Hirte, T. M. J. Möllers, Köln-Berlin-München 2007.

Moloney N., EU Securities and Financial Markets, Oxford 2014.

Mülbert P. O., Auswirkungen der art. 19 ff MiFID auf das Zivilrecht am Beispiel von Vertriebsvergütungen im Effektengeschäft der Kreditinstitute, „Zeitschrift für das gesamte handelsrecht" 2008, no. 172.

Mülbert P. O., The Eclipse of Contract Law in the Investment Firm-Client Relationship: The Impact of the MiFID on the Law of Contract from a German Perspective, in: Investor Protection in Europe. Corporate Law Making, The MiFID and Beyond, ed. G. Ferrrarini, E. Wymeersch, Oxford 2007.

Pistor K., Xu C., Fiduciary Duty in Transitional Civil Law Jurisdictions Lessons from the Incomplete Law Theory, in: Global Markets, Domestic Institutions: Corporate Law and Governance in a New Era of Cross-Border Deals, ed. C. J. Milhaupt, New York 2003. 
Radwański Z., Olejniczak A., Zobowiqqzania-częśc ogólna, Warszawa 2014.

Szpunar A., in: System prawa cywilnego. Prawo zobowiązań, częś́ ogólna, vol. 3, part 2, ed. Z. Radwański Wrocław 1981.

Tison M., The civil law effects of MiFID in a comparative law perspective, in: Festschrift für Klaus J. Hopt. Unternehmen, Markt und Verantwortung, Berlin-New York 2010.

Zacharzewski K., Szkoda gietdowa i jej naprawienie, Toruń 2015.

Zapadka P., in: Prawo rynku kapitatowego. Komentarz, ed. M. Wierzbowski, L. Sobolewski, P. Wajda, Warszawa 2014.

\section{SUMMARY}

\section{The Civil Liability of Asset Managers - a Polish Perspective ${ }^{75}$}

This paper focuses on the civil liability of asset managers in Polish law. Following the transformation of the economic system and the development of the capital market in Poland, the importance of asset management has been gradually increasing, though it remains disproportionally lower when compared to the role of collective asset management in the form of investment funds. The chief purpose of both MiFID directives is to harmonize the rules applicable to investment firms providing brokerage services in Europe, and to protect the interests of investors using brokerage services. Although the civil liability of investment firms offering brokerage services is part of what is broadly construed as investor protection, the regulations on this matter have been left to the member states' discretion. There is no doubt that discrepancies between member states in this respect diminish the harmonizing effect of both directives. This paper sets out to determine the basic rules of civil liability of asset managers in Polish law, and present suggestions for the most common problems in this field.

Keywords: civil liability, brokerage services, asset management, MiFID, harmonization.

Tomasz SójкA, Adam Mickiewicz University Poznań, Faculty of Law and Administration, A1. Niepodległości 53, 61-714 Poznań, Republic of Poland, e-mail: tomasz.sojka@amu.edu.pl.

75 This publication is a result of a project financed by National Centre of Science (Narodowe Centrum Nauki) according to the decision no DEC-2013/09/B/HS5/00289. 
